\title{
Statin pretreatment diminishes the levels of myocardial ischemia markers not only in CABG
}

\author{
José Martínez-Comendador, José Rubio Álvarez, José Benito Garcia Bengochea
}

\begin{abstract}
A response to Ege E, Dereli $Y$, Kurban S, Sarigul A: Atorvastatin pretreatment diminishes the levels of myocardial ischemia markers early after CABG operation: an observational study. J Cardiothorac Surg 2010, 5:60.
\end{abstract}

\section{Correspondence}

We read with great interest the manuscript by Ege et al [1] concerning how Atorvastatin pretreatment before CABG diminishes the levels of myocardial ischemia biomarkers.

Our study [2] was the first to report that preoperative treatment with statins reduces biochemical parameters of systemic inflammatory response and myocardial ischemia markers in cardiac surgery with cardiopulmonary bypass $(\mathrm{CPB})$, regardless of being $\mathrm{CABG}$ or valvular surgery.

Mannacio et al [3] published the first randomized study showing that pretreatment with rosuvastatin decreases the incidence of myocardial damage in patients undergoing coronary surgery with $\mathrm{CPB}$. In our study Creatine phosphokinase (CPK), CPK-MB and troponin I was assessed at 1,6 , and $24 \mathrm{~h}$ after surgery in 138 patients who underwent cardiac surgery with CPB.

The levels observed in the statin treatment group were always lower than those in the group that did not receive treatment, this difference only being significant in the measurement of CPK-MB at $24 \mathrm{~h}(19.7 \pm 23 \mathrm{ng} / \mathrm{ml}$ vs $33.1 \pm 32.6 \mathrm{ng} / \mathrm{ml}, \mathrm{p}=0.02)$ and in the sample collected of Troponin I at the end of the intervention (2.25 $\pm 2.2 \mathrm{ng} / \mathrm{ml}$ vs $3.32 \pm 3.1 \mathrm{ng} / \mathrm{ml}, \mathrm{p}=0.03)$ and at $24 \mathrm{~h}$ $(4.15 \pm 3.54 \mathrm{ng} / \mathrm{ml}$ vs $6.64 \pm 8.08 \mathrm{ng} / \mathrm{ml}, \mathrm{p}=0.04)$. These findings coincide with the single measurement at $24 \mathrm{~h}$ after surgery in the manuscript by Ege et al (for CK-MB levels, $12.9 \pm 4.3$ versus $18.7 \pm 7.4 \mathrm{ng} / \mathrm{ml}, \mathrm{p}=0.004$; for troponin I levels, $1.7 \pm 0.3$ versus $2.7 \pm 0.7 \mathrm{ng} / \mathrm{ml}$,

\footnotetext{
* Correspondence: josemmcomendador@gmail.com Department of Cardiovascular Surgery, University Hospital Santiago de Compostela (CHUS). SERGAS. Travesia da Choupana s/n, Santiago de Compostela,15706 A Coruña, Spain
}

(c) 2010 Martínez-Comendador et al; licensee BioMed Central Ltd. This is an Open Access article distributed under the terms of the Creative Commons Attribution License (http://creativecommons.org/licenses/by/2.0), which permits unrestricted use, distribution, and reproduction in any medium, provided the original work is properly cited. we found in our study could be explained by the mixed valvular and coronary population, beeing similar with the findings of Landoni $\mathrm{G}$ et al [4]. This study demonstrated that each type of cardiac operation has a peculiar amount of myocardial necrosis biomarkers; the highest release of these cardiac biomarkers was associated with mitral valve replacement [4].

Ege et al [1] reports that the study group received minimum $20 \mathrm{mg} / \mathrm{kg} /$ day atorvastatin (Ator, Sanovel, Istanbul, Turkey) for at least 15 days before surgery, and we assume that they wish to mean $20 \mathrm{mg} /$ day atorvastatin.

The type of statin we used most was atorvastatin (63.9\%) and the most common dose was $20 \mathrm{mg}$ per day at least 3 weeks before surgery [2]. Mannacio et al [3] used $20 \mathrm{mg} /$ day of rosuvastatin one week before surgery. Therefore, it seems possible to achieve the same results, even with low doses of statins and in less time before surgery.

Recent studies performed in patients undergoing cardiac surgery found that statins reduced the mid-term mortality and the number of postoperative complications and clinical events[5]; the common feature of these publications were the large amount of patients necessary to achive clinical results. Ege et al [1] found a shorter duration of ICU stay among patients treated with atorvastatin in an study with only forty cases. In our prospective cohort of 138 patients [2], the different groups analyzed did not show differences with regard to any of the postoperative variables. Therefore, this results should be interpreted cautiously, until future studies with larger sample sizes confirm these findings.

In CABG without myocardial infarction, the amount of cardiac biomarker released seemed to be associated 
with an increased risk of mortality and late cardiac events [6]. According to this facts an absolute reduction of marker release, as observed in these studies [1-3], could be translated into a reduction of early and late adverse events. The anti-inflammatory action of statins, as we demonstrated [2], its pleiotropic effects and the capacity of reduction of myocardial biomarkers, are the reasons of the potencial beneficial effects of statins in cardiac surgery interventions.

\section{List of abbreviations}

CABG: Coronary artery bypass graft; CPB: Cardiopulmonary bypass; CPK:

Creatine phosphokinase.

\section{Authors' contributions}

The authors read and approved the final manuscript.

\section{Competing interests}

The authors declare that they have no competing interests.

Received: 12 November 2010 Accepted: 29 December 2010

Published: 29 December 2010

\section{References}

1. Ege E, Dereli $Y$, Kurban S, Sarigul A: Atorvastatin pretreatment diminishes the levels of myocardial ischemia markers early after CABG operation: an observational study. J Cardiothorac Surg 2010, 5:60.

2. Martinez-Comendador JM, Alvarez JR, Mosquera I, Sierra J, Adrio B, Carro JG, Fernandez A, Bengochea J: Preoperative statin treatment reduces systemic inflammatory response and myocardial damage in cardiac surgery. Eur J Cardiothorac Surg 2009, 36:998-1005.

3. Mannacio VA, lorio D, De Amicis V, Di Lello F, Musumeci F: Effect of rosuvastatin pretreatment on myocardial damage after coronary surgery: a randomized trial. J Thorac Cardiovasc Surg 2008, 136:1541-1548.

4. Landoni G, Pappalardo F, Calabro MG, Boroli F, Sottocorna O, Aletti G, Crescenzi G, Zangrillo A: Myocardial necrosis biomarkers after different cardiac surgical operations. Minerva Anestesiol 2007, 73:49-56.

5. Vaduganathan M, Stone NJ, Lee R, McGee EC, Malaisrie SC, Silverberg RA, McCarthy PM: Perioperative statin therapy reduces mortality in normolipidemic patients undergoing cardiac surgery. J Thorac Cardiovasc Surg 2010, 140:1018-1027.

6. Petaja L, Salmenpera M, Pulkki K, Pettila V: Biochemical injury markers and mortality after coronary artery bypass grafting: a systematic review. Ann Thorac Surg 2009, 87:1981-1992.

doi:10.1186/1749-8090-5-131

Cite this article as: Martínez-Comendador et al:: Statin pretreatment diminishes the levels of myocardial ischemia markers not only in CABG. Journal of Cardiothoracic Surgery 2010 5:131.

\section{Submit your next manuscript to BioMed Central} and take full advantage of:

- Convenient online submission

- Thorough peer review

- No space constraints or color figure charges

- Immediate publication on acceptance

- Inclusion in PubMed, CAS, Scopus and Google Scholar

- Research which is freely available for redistribution

Submit your manuscript at www.biomedcentral.com/submit
Biomed Central 